\title{
The Analysis of Financial Sustainability Ratio on Rural Banks in Indonesia
}

\author{
Indra Saputra $^{1}$, Sekar Mayangsari ${ }^{2}$ \\ \{Indra.saputra@trisakti.ac.id¹, Sekar_mayangsari@trisakti.ac.id²\} \\ Faculty of Economics and Business, Universitas Trisakti
}

\begin{abstract}
The purpose of this study is to examine and analyze the financial performance ratios consisting of return on assets, non-performing loans, mobilization deposits on financial sustainability ratio in rural bank institutions in Indonesia. Target population of this study was the rural bank Registered and supervised by the Financial Services Authority (OJK) in 2018-2020. With the sampling method selected based on the purposive sampling criteria, totaling 71 companies with 213 observations. Data analysis consists of descriptive and multiple regression linear regression processed using SPSS statistical tools. The results show that the return on assets has a significant positive effect and nonperforming loan has a significant negative effect on the financial sustainability ratio. The results illustrate that the greater the company's ability to generate profits the higher the value of the company's financial sustainability and vice versa. Whereas non-performing loan describes the company's ability to manage its financing and the results illustrate that if there is an increase in nonperforming loans it will happen a decrease in the condition of the company's financial sustainability. Variable mobilization deposit no has an influence on the company's financial sustainability, this illustrates that the greater the amount of funds that can be collected by the bank if it cannot be channeled through the provision of credit to customers it will not have an impact on sustainability because it is considered that these funds do not contribute to financial performance such as for the development and return of operating results and vice versa there are indications that can affect the decline in the company's financial sustainability condition due to prove to have a negative relationship. Furthermore, the size of the company cannot determine the company's financial sustainability.
\end{abstract}

Keywords: Return On Asset (ROA); Non-Performing Loan (NPL); Mobilization Deposit (MD); Financial Sustainability Ratio (FSR)

\section{Introduction}

Economic activities in Indonesia, especially the financial sector, are strongly supported by financial institutions in Indonesia. Financial institutions are the sector that has the greatest influence on the economic activities of modern society. Micro-enterprises are one of the sectors that have an important role in the economy, but so far this sector has been difficult to 
develop, because micro-entrepreneurs who generally come from the lower classes of society are barely touched (underserved) and are considered to have no potential for funds by formal financial institutions, especially financial institutions. conventional finance, thus hampering the pace of its development. Limited access to sources of financing faced by Micro, Small and Medium Enterprises (MSMEs) to banks, causes them to depend on informal sources and Micro Finance Institutions (MFIs). MFIs are institutions that provide financial services for micro-entrepreneurs and low-income communities, both formal, semi-formal and informal.

Based on the United Nations declaration regarding the year of microfinance institutions in 2005 (international year of microfinance) it is highly recommended to realize the research agenda on the sustainability of MFIs. Several studies on MFIs have focused on assessing the performance and sustainability of MFIs by evaluating financial indicators that directly affect the level of independence, outreach and mechanisms of lending. The findings of Chaves and Vega reveal that the success of MFIs in Indonesia is a result of the organization's design. They argue that the design of an organization that will intermediary for financial services is very important because it will determine the performance of the MFI and ultimately determine its success or failure (Chaves and Vega, 1996). Rural Banks (BPR) as one of the actors in the microfinance market have their own role in the community and micro, small and medium enterprises (MSMEs). Based on POJK No. 20/POJK.03/2014 concerning Rural Banks, to encourage national economic growth and support dynamic business development, a strong national banking system is needed, including a Rural Bank industry that is healthy, strong, productive, and competitive in order to be able to serve community, especially micro and small enterprises.

Microfinance institutions (MFIs) must understand that long-term sustainability can be achieved only with proper financial conditions. Therefore, rural banks (BPR) that are healthy, strong, productive, and competitive will have long-term sustainability. Sustainability refers to the company's ability to meet all costs with its own operating income. According to Rivera (2003), for microfinance institutions (MFIs), sustainability refers to the MFI's ability to achieve future goals and maintain them. To achieve financial sustainability, MFIs need to minimize costs, offer products and services that meet client needs, increase innovation to reach the unbanked poor and increase income to cover costs. Based on The Consultative Group to Assist the Poor (CGAP), which is a consultative group to help the poor under the auspices of the World Bank, the standard value for FSR is above $100 \%$. The greater the FSR of a bank, the greater the ability of a bank to continue its operations. By using the FSR ratio, information about the sustainability and growth rate of the bank in the long term can be obtained.

There are several studies on financial sustainability that show inconsistent findings. The results of Budiarti's research Return on Assets (ROA) has a positive effect on the financial sustainability ratio (FSR), but contradicts the results of Wahyuni and Fakhruddin's research which states that ROA has a negative effect on FSR [1], [2]. The results of research by Almilia, et al stated that Non-Performing Loans (NPL) had a negative effect on the financial sustainability ratio (FSR), but contradicted the results of Fadhila's research which stated that NPL growth had no positive effect on FSR [3], [4]. The results of Nyamsogoro's research (2009) state that the Cash Ratio has an effect on the financial sustainability ratio (FSR), but contradicts the results of Mussa's research which states that the Cash Ratio has no effect on FSR [5]. The results of research by Almilia, et al stated that the Loan to Deposit Ratio (LDR) had a negative effect on the financial sustainability ratio (FSR), but contradicted the results of Budiarti's research which stated that the growth of LDR had a positive effect on FSR [1], [3]. The results of Tehulu's research state that Bank Size has a positive effect on the financial 
sustainability ratio (FSR), but contradicts the results of Bogan et al research which states that Bank Size has a negative effect on FSR [6], [7]. The results of Ndambu's research state that Deposit Mobilization has a positive effect on the financial sustainability ratio (FSR), but contradicts the results of Marwa and Meshach's research which states that Deposit Mobilization has a negative effect on FSR [8], [9]. The results of research by Bogan, et al stated that Bank Age had a positive effect on the financial sustainability ratio (FSR), but contradicted the results of research by Rahman and Mazlan which stated that Bank Age had a negative effect on FSR [7], [10].

The results of the research by Nyankomo Marwa and Meshach Aziakpono show that, about 61 percent of the sample of SACCOs companies are operationally sustainable and 51 percent of the total sample are both operationally and financially sustainable [9]. The average sustainability score is 127 percent. The average yield for profitability (measured by ROA) is higher than some reported results for regional and global microfinance standards. In terms of sustainability, the future forecast results are promising for the financial cooperative business model as an alternative form of financing. Soheil Kezemian et al (2016) found that the current research provides some empirical evidence that following customer orientation significantly affects the sustainability of AIM's management and financial sustainability. However, competitor orientation does not have a statistically significant impact on the sustainability of AIM. In contrast, only the continuity of AIM management is significantly affected by interfunctional coordination.

Surprisingly, deposit mobilization affects financial sustainability scores negatively. It is theoretically expected that high deposit mobilization will lead to a lower cost of capital and hence a high level of financial sustainability, but empirical evidence suggests otherwise. The observed differences can be explained by the possibility that SACCOs with high deposit mobilization may be located in areas where there is a low level of institutional thickness, which is detrimental to the operating environment and low relationships with other financial institutions which might lead to high transaction costs. Detailed qualitative follow-up is needed to understand the main drivers of the observed behavior. As expected, the higher cost per loan portfolio had a negative effect on financial sustainability. It is important that SACCOs whose cost per loan portfolio is above 20 percent should design innovative solutions to cut costs based on their operating environment. Based on the research gap, further research is needed to analyze the effect of ROA, NPL, Deposit Mobilization on the financial sustainability ratio (FSR) at Rural Banks in Indonesia during 2018-2020.

\section{Literature Review}

\subsection{Sustainability}

Sustainability theory of Microfinance Institutions (MFIs) that has been developed so far states that MFI sustainability is the MFI's ability to run the system that has been built so that it can operate sustainably. Likewise, MFIs have the ability as microfinance providers to cover all costs in achieving financial sustainability. The system in the concept of sustainability of sharia MFIs is measured based on sharia compliance finance which refers to sufficient income to cover capital costs and funding costs. Income and capital costs in sharia MFIs are obtained not from ribawi transactions, tadlis, speculative behavior, gambling and gharar. MFI sustainability is the MFI's ability to survive, continuously in covering operational costs by using operating income generated from business activities. 
In general, experts examine sustainability with two approaches, namely the welfare approach and the institutional approach. According to Murdock, in the microfinance movement in the world in terms of reaching the poor through providing access to financial services, there are two main approaches, namely the institutional approach (institutionist approach) and the welfare approach (welfarist approach). Research shows that microfinance institutions are significantly characterized by an institutional approach to sustainability (Murdock, 2000). The institutional approach focuses on creating financial institutions to reach customers who are not served by the formal financial system. The emphasis on institutions lies in achieving financial self-sufficiency, breadth of outreach, which means the number of customers served, and the positive client impact. Meanwhile, the welfare approach emphasizes the depth of outreach, which means the level of the poorest community served. This approach does not always look at the institutional side, but emphasizes the impact of financial services on the economically active poor.

\subsection{Life Cycle Theory}

Based on Mersland and Ludovic, Fehr and Hishigsuren, the application of Life Cycle Theory is used to understand the capital requirements of MFIs [11], [12]. Life Cycle Theory can also serve as a framework for understanding the commercialization of microfinance institutions (MFIs) and the impact of that process on profitability and costs. Phases in Life Cycle Theory are divided into three namely; growth, youth and mature. In the growth phase of Microfinance Institutions (MFIs), MFIs try to be financially independent.

MFIs in this phase are at high risk and require capital subsidies in the form of grants and capital contributions to support the early years of operation because MFIs are not yet able to attract commercial funds. Donations, subsidies and soft loans are included in the source of funding for this stage. In the early stages, it can be ascertained that the MFI does not qualify to receive any source of commercial funding. In the Youth Microfinance Institution (MFI) phase, efficiency increases, savings and payment services are offered and profitability can be achieved.

MFIs in this phase must scale up and gain market share while maintaining profits. MFIs have become financially independent, private capital loans become available. Management performance is a prerequisite for obtaining external funding. In the mature phase of Microfinance Institutions (MFIs), MFIs become more profitable and seek to further improve their efficiency. Often, at this phase the MFI is in a strong competitive environment. At this stage the traditional sources of bank funds are available. The traditional sources of bank funds are in the form of savings and time deposits.

\subsection{Previous Empirical Studies}

The results of the research by Nyankomo Marwa and Meshach Aziakpono show that, about 61 percent of the sample of SACCOs companies are operationally sustainable and 51 percent of the total sample are both operationally and financially sustainable [9]. The average sustainability score is 127 percent. The average yield for profitability (measured by ROA) is higher than some reported results for regional and global microfinance standards. In terms of sustainability, the future forecast results are promising for the financial cooperative business model as an alternative form of financing. Soheil Kezemian et al found that the current research provides some empirical evidence that following customer orientation significantly affects the sustainability of management and financial sustainability [13]. However, 
competitor orientation does not have a statistically significant impact on the sustainability. In contrast, only the continuity of management is significantly affected by inter-functional coordination.

The results of Budiarti's research state that Return on Assets (ROA) has a positive effect on the financial sustainability ratio (FSR), but contradicts the results of Wahyuni and Fakhruddin's research which states that ROA has a negative effect on FSR [1], [2]. The results of research by Almilia, et al stated that Non-Performing Loans (NPL) had a negative effect on the financial sustainability ratio (FSR), but contradicted the results of Fadhila's research which stated that NPL growth had no positive effect on FSR [3], [4]. The results of Nyamsogoro's research (2009) state that the Cash Ratio has an effect on the financial sustainability ratio (FSR), but contradicts the results of Mussa's research which states that the Cash Ratio has no effect on FSR. The results of research by Almilia, et al stated that the Loan to Deposit Ratio (LDR) had a negative effect on the financial sustainability ratio (FSR), but contradicted the results of Budiarti's research which stated that the growth of LDR had a positive effect on FSR [1], [3], [5]. The results of Tehulu's research state that Bank Size has a positive effect on the financial sustainability ratio (FSR), but contradicts the results of Bogan et al research which states that Bank Size has a negative effect on FSR [6], [7]. The results of Ndambu's research state that Deposit Mobilization has a positive effect on the financial sustainability ratio (FSR), but contradicts the results of Marwa and Meshach's research which states that Deposit Mobilization has a negative effect on FSR [8], [9]. The results of research by Bogan, et al stated that Bank Age had a positive effect on the financial sustainability ratio (FSR), but contradicted the results of research by Rahman and Mazlan which stated that Bank Age had a negative effect on FSR [7], [10].

\subsection{Conceptual Framework}

Crystallization from literature review and empirical studies as described above produces a conceptual framework as shown in the figure 1.

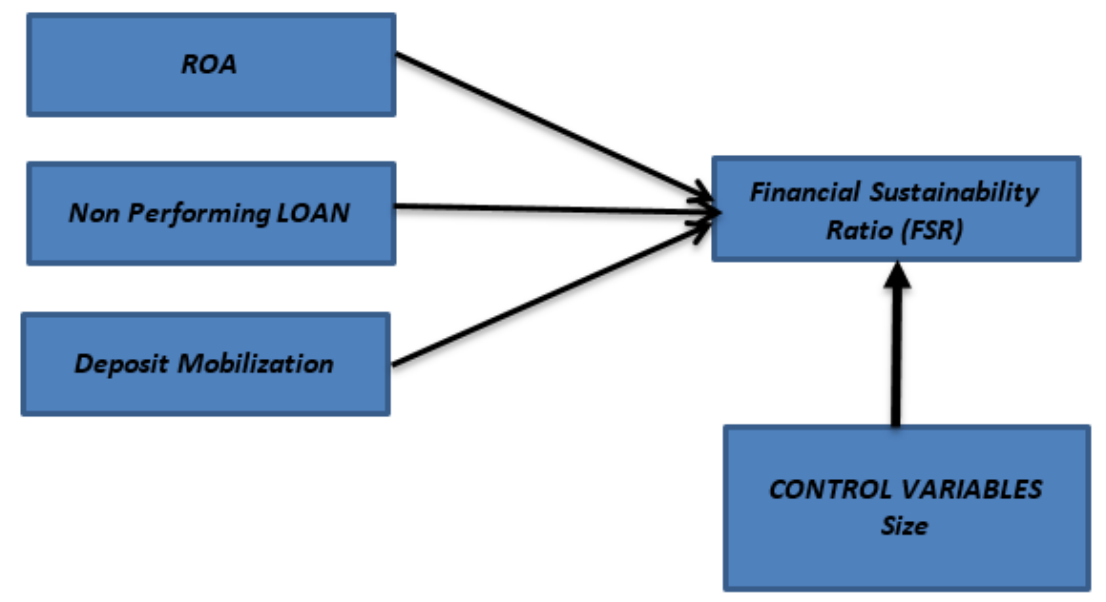

Fig. 1. Research Conceptual Framework 


\subsection{Research Hypothesis}

\subsubsection{The effect of Return on Asset (ROA) on Financial Sustainability Ratio (FSR)}

ROA is used to measure the effectiveness of the company in generating profits by utilizing its assets, so that ROA can show how the company's ability to generate profits from time to time. The previous year's Return on Assets (ROA) is the previous year's profit before interest and tax as a percentage of the previous year's total assets. Based on SE BI No. 13/24/DPNP In 2011 , the criteria for an adequate ROA assessment is above $1.5 \%$. The greater the ROA of a bank, the greater the level of profit achieved by the bank and the better the position of the bank in terms of the use of its assets so that the bank's ability to continue to be a going concern is higher. The lower the ROA, the greater the probability that the bank is in troubled condition [3]. The results of research conducted by Budiarti show that ROA has a positive and significant effect on financial sustainability [1]. In life cycle theory, efforts to increase ROA will bring banks into phase II (youth) and then move up to phase III (mature). Because in both phases the efficiency of the bank increases and the bank is considered more profitable. The greater the ROA value achieved means the bank's profit is also large, the previous year's profit will increase the bank's funds to be used in lending. In other words, current income is obtained from the use of the previous year's profit through lending and other investments so that the hypothesis in this study is:

H1: Return on Assets (ROA) has a significant positive effect on the Financial Sustainability Ratio (FSR)

\subsubsection{The effect of Non Performing Loans (NPL) on Financial Sustainability Ratio (FSR)}

The NPL ratio is part of the bank's performance assessment, when the NPL value exceeds the limit, the bank will be considered problematic. The results of research conducted by Budiarti show that the direction of the relationship between NPL growth and financial sustainability shows a negative and significant direction [1]. This shows that there are indications that if there is an increase in NPL, there will be a decrease in the condition of financial sustainability. In life cycle theory, a high NPL will bring the bank to a decline stage and the growth, youth and mature phases cannot be achieved. Because in each phase in life cycle theory requires conditions that tend to be low NPL. The increase in the NPL value indicates an increase in the number of non-performing loans experienced, non-performing loans will make it difficult for banks to withdraw funds that have been issued. Sometimes banks withdraw their funds from depositors with the help of third parties which of course costs money. And sometimes the non-return of the loan principal and interest on the loan will make the cash flow for the new loan disrupted, thus affecting the interest income that should be obtained. The emergence of collection fees and a decrease in interest income will affect the decline in the Financial Sustainability Ratio (FSR). Based on this description, the following hypothesis is:

H2: Non-Performing Loans (NPL) have a significant negative effect on the Financial Sustainability Ratio (FSR)

\subsubsection{The effect of Deposit Mobilization (DM) on Financial Sustainability Ratio (FSR)}

The impact of raising funds on income will be seen in the deposit-to-asset ratio, funds from customers are the main source of funding and may also be the cheapest source of funding for 
banks, in general the impact of customer deposits on performance is positive . as long as the demand for credit tends to be high, if the demand for credit tends to be low, customer funds will actually reduce profits. The results of research conducted by Ndambu show that the deposit mobilization variable has a significant positive effect on financial sustainability [8]. This means that an increase in the deposit mobilization variable will also increase its financial sustainability. In life cycle theory, increased deposit mobilization will bring the bank to phase II (youth) and then to phase III (mature). Because in both phases, savings services began to be improved and banks in phase III were characterized as banks with large customer bases. Based on this description, the following hypothesis is:

H3: Deposit Mobilization (DM) has a significant positive effect on the Financial Sustainability Ratio (FSR)

\section{Research Methodology}

\subsection{Research Design}

The research design used in this study is hypothesis testing, which aims to examine the effect of return on asset, non-performing loans and deposit mobilization on financial sustainability ratio and This study uses secondary data obtained from the official website of the Indonesia Stock Exchange (www.idx.co.id) and the company's website. The unit of analysis in this research is financial corporation classified as rural bank registered and supervised by the financial service authority in Indonesia.

\subsection{Variable and Measurement}

\subsubsection{Dependent Variable: Financial Sustainability Ratio (FSR)}

Financial Sustainability Ratio (FSR) is a ratio to measure the sustainability of a bank in terms of bank financial performance. Besides that, it is also a target for increasing own capital. Financial Sustainability Ratio (FSR) can be used to determine the company's ability to generate and increase returns in order to achieve and maintain its long-term existence [4].

\subsubsection{Independent Variable}

ROA is used to measure the effectiveness of the company in generating profits by utilizing its assets, so that ROA can show how the company's ability to generate profits from time to time. The previous year's Return on Assets (ROA) is the previous year's profit before interest and tax as a percentage of the previous year's total assets. NPL can be used to measure the extent of non-performing loans experienced by a bank. The NPL ratio is a description of nonperforming loans, the cause of which is the customer's inability to pay installments on the principal and interest charged in accordance with the agreement. The criteria for the NPL ratio according to the Rural Bank Business Model (2011) is below 5\%. The deposit to asset ratio is used to measure the amount of assets funded by public deposits. This ratio provides an analysis of information about the role of deposits as a source of funding [14]. 


\subsection{Population and Sample}

In this study, the population used were all Conventional Rural Banks in Indonesia during the 2018-2020, The research sample was taken by purposive sampling, which is where the sample selection method is based on population characteristics that have been previously known with the following criteria:

a. Conventional Rural Banks in Indonesia registered with the Financial Services Authority that are consistent throughout the research period (2018 to 2020).

b. Conventional Rural Banks in Indonesia that present complete financial statement data and ratios according to the variables to be studied during the research period (2018 to 2020) and published by the Financial Services Authority.

\subsection{Analysis Method}

The analytical method used consists of:

a) Research Model

This study employed a multiple regression analysis method. This analysis is used to test the effect of the independent variable on the dependent variable. The multiple regression equation model used in this study is as follows.

$\mathrm{FSR}=\alpha+\beta 1 \mathrm{ROA}+\beta 2 \mathrm{NPL}+\beta 3 \mathrm{MD}+\beta 4 \mathrm{Size}+\mathrm{e}$

Notes:

$\alpha \quad=$ Constanta

$\beta 1-\beta 5=$ Koefesien

FSR $=$ Finacial Sustainability Ratio

ROA $=$ Return On Asset

NPL $=$ Non Performing Loan

MD = Mobilization Deposit

Size $\quad=$ Size

$\mathrm{e} \quad=$ Error

b) Analysis Data

1) Descriptive Statistics

Descriptive statistics are used to describe the sample data profile which includes, among others, the mean, range, and standard deviation. Descriptive statistics are part of statistics that focus on collecting, presenting, processing, and summarizing data where this activity does not continue to draw conclusions. Through descriptive statistics, the preparation of data in lists or tables and visualization in the form of diagrams or graphs is carried out.

2) Data Normality Test

The normality test used was the Kolmogorov-Smirnov non-parametric statistical test. This test tool is used to provide more detailed figures in order to confirm whether there is normality or not from the data used. According to Ghozali normality can occur if the results of the Kolmogorov-Smirnov test are more than 0.05 [15]. The significance value of normally distributed residuals if the Asymp.Sig (1-tailed) value in the One-Sample Kolmogorov-Smirnov Test is greater than 0.05 , it can be concluded that in the ANOVA there are residual or confounding variables that are 
normally distributed.

3) Classical Assumption Test

Multiple linear regression model can be referred to a good model if it meets BLUE criteria (Best Linear Unbiased Estimator). BLUE criteria can be achieved when it meets classical assumption. The classical assumption that will be tested in this study, such as multicolinearity test, autocorrelation test, heteroscedasticity test and normality regression test.

\section{Results and Discussion}

\subsection{Descriptive Statistics of Research Variables}

This study uses variables, return on asset, non-performing loan and deposit mobilization as independent variables and financial sustainability ratio as the dependent variable is presented in the table 1 below:

Table. 1. Descriptive Statistics

\begin{tabular}{cccccc}
\hline & $\mathbf{N}$ & Minimum & Maximum & Mean & Std. Deviation \\
\hline FSR & 213 & .28 & 1.81 & 1.0854 & .23403 \\
ROA & 213 & -.36 & .19 & .0680 & .06119 \\
NPL & 213 & .00 & 60.42 & 11.0927 & 9.75738 \\
DM & 213 & .00 & .89 & .4713 & .23227 \\
SIZE & 213 & 21.66 & 27.66 & 24.3019 & 1.20508 \\
\hline
\end{tabular}

From the results of descriptive statistical tests, it can be seen that the Financial Sustainability Ratio variable has a minimum value of 0.28 , with a maximum value of 1.81 , the average Financial Sustainability Ratio of 213 observations is 1.0854 with a standard deviation of 0.23403 . The Return on Assets variable has a minimum value of -0.36 , with a maximum value of 0.19 , the average Return on Assets from 213 observations is 0.0680 with a standard deviation of 0.06119 . The Non-Performing Loan variable has a minimum value of 0.00 , with a maximum value of 60.42, the average Non-Performing Loan from 213 observations is 11.0927 with a standard deviation of 9.75738. The Deposit Mobilization variable has a minimum value of 0.00 , with a maximum value of 0.89 , the average Deposit Mobilization of 213 observations is 0.4713 with a standard deviation of 0.23227 . Variable Size has a minimum value of 21.66 , with a maximum value of 27.66 , the average size of 213 observations is 24.3019 with a standard deviation of 1.20508 .

\subsection{Classic assumption test}

The purpose of this test is to see whether the regression model used has met the classical assumption test in analyzing data.

\subsubsection{Normality test}

The purpose of doing the normality test is to test whether the regression model, the residual of the dependent variable and the independent variable or both have a normal distribution or not using the One-Sample Kolmogorov-Smirnov Test and the results of the normality test of this study are shown in the following table 2: 
Table 2. Normality test results

\begin{tabular}{cccc}
\hline Information & Significance Traffic & Asymp. Sig. (2-tailed) & Decision \\
\hline $\begin{array}{c}\text { Multiple Regression } \\
\text { Equation }\end{array}$ & 0.05 & 0.280 & $\begin{array}{c}\text { Normally } \\
\text { distributed data }\end{array}$ \\
\hline
\end{tabular}

Based on the One-Sample Kolmogorov-Smirnov Test it can be seen that the Asymp. Sig = $0.280>0.05$ means that the data is normally distributed.

\subsubsection{Multicollinearity Test}

Based on the results of the multicollinearity test, the following can be shown:

Table 3. Multicolonierity Test Results

\begin{tabular}{|c|c|c|c|}
\hline \multirow[t]{2}{*}{ Model } & \multicolumn{2}{|c|}{ Collinearity Statistics } & \multirow[t]{2}{*}{ Conclusion } \\
\hline & Tolerance & VIF & \\
\hline Return on Asset & .842 & 1.188 & No Multicollinearity \\
\hline Non-Performing Loan & .837 & 1.195 & No Multicollinearity \\
\hline Deposit Mobilization & .674 & 1.484 & No Multicollinearity \\
\hline Size & .603 & 1.658 & No Multicollinearity \\
\hline
\end{tabular}

From the table above it is known that each variable has a value Variance Inflation Factor (VIF) is less than 10, it shows that there is no multicollinearity (there is no strong relationship between the independent variables).

\subsubsection{Autocorrelation Test}

Based on the results of the autocorrelation test, the following can be shown:

Table 4. Autocorrelation Test Results

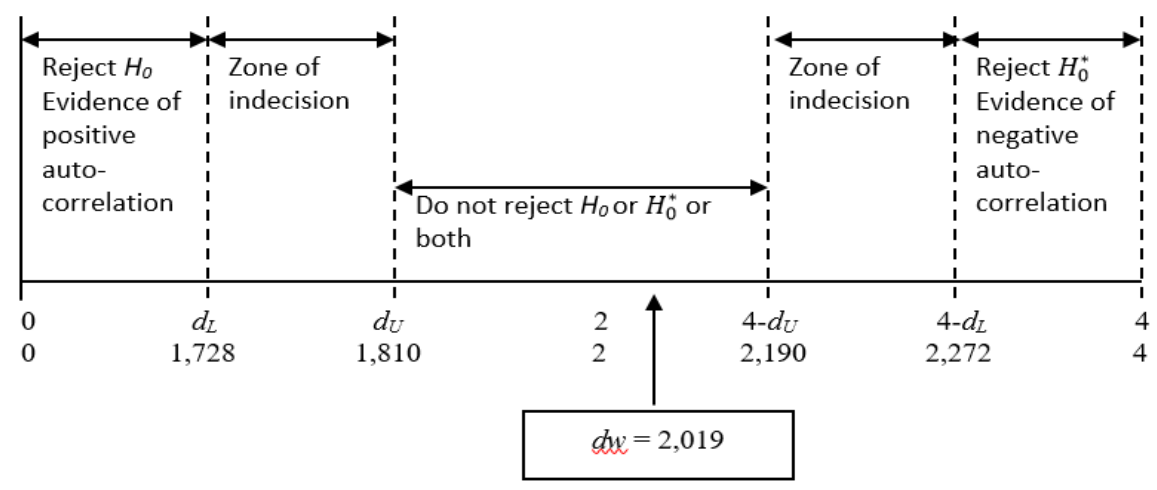

Autocorrelation test shows that the value of $\mathrm{dw}$ statistic is in the area where $\mathrm{dU}<\mathrm{dw}<4$ $\mathrm{dU}$ or $\mathrm{dw}$ statistic is where the value of $\mathrm{dw}$ is 2.019 which is greater than the upper durbin value of 1.810 but smaller than the upper 4-durbin's value of $2.190(1.810<2.019<2.190)$. This value indicates that the $\mathrm{dw}$ statistic falls into the criteria of do not reject $\mathrm{H} 0$ or there is no autocorrelation, so the researcher concludes that there is no autocorrelation from the regression model used in this study. 


\subsubsection{Heteroscedasticity Test}

Based on the scatterplot graph to analyze whether heteroscedasticity occurs or does not occur heteroscedasticity by observing the distribution of dots in the image below. From Figure 2 , it can be seen that the scatter points are random and scattered both above and below the number 0 on the $\mathrm{Y}$ axis, so it can be concluded that there is no heteroscedasticity in the regression model.

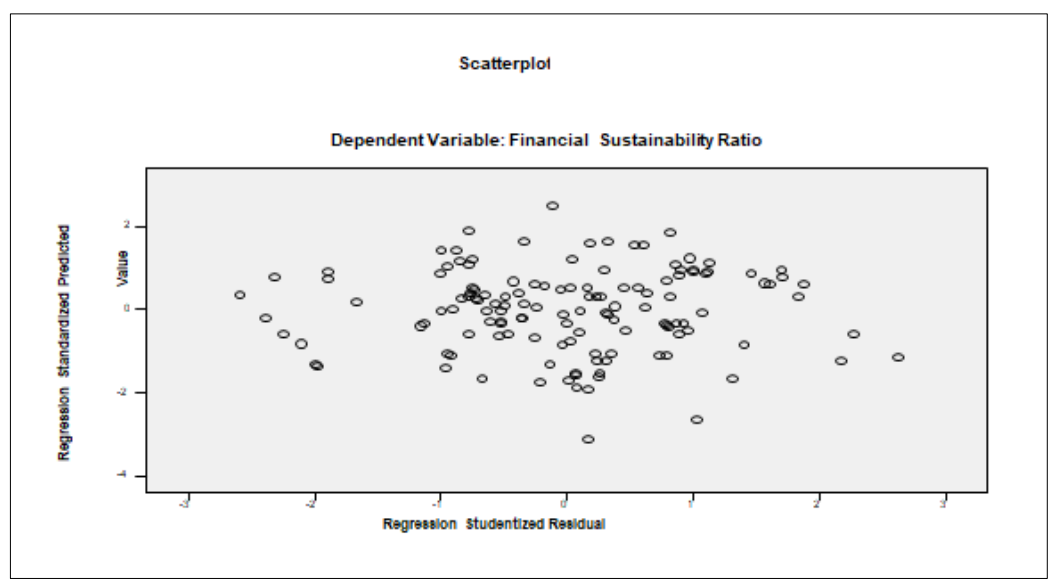

Fig.1. Scatterplot graph

\subsection{Analysis and Discussion}

Table 5. F Test Results

\begin{tabular}{cccc}
\hline Information & F & Sig & Adjusted R Square \\
\hline Multiple Regression Equation & 0.05 & 0.000 & 0.429 \\
\hline
\end{tabular}

The significance value of return on asset, non-performing loans,deposit mobilization and size is 0.000 where $<0.05$, it can be concluded that together the independent variables significantly influence the dependent variable. Meanwhile, the adjusted R-Square value of 0.429 or $9.4 \%$ means that the independent variables return on asset, non-performing loans,deposit mobilization and size jointly affect financial sustainability ratio.

Table 6. Hypothesis Testing Results ( $t$ test)

\begin{tabular}{lccccc}
\hline Variabel & Koefisien & t-statistik & $\begin{array}{c}\text { Sig. } \\
\text { 2-tailed }\end{array}$ & $\begin{array}{c}\text { Sig. } \\
\text { 1-tailed }\end{array}$ & Decision \\
\hline (Constant) & 0,787 & 2,609 & 0,010 & & \\
ROAt_1 & 1,752 & 8,094 & 0,000 & 0,000 & H1 Accepted \\
NPL & $-0,008$ & $-6,117$ & 0,000 & 0,000 & H2 Accepted \\
DM & $-0,028$ & $-0,434$ & 0,665 & 0,332 & H3 Rejected \\
SIZE & 0,012 & 0,904 & 0,367 & & \\
R-Square & 0,440 & & & & \\
Adjusted $R^{2}$ & 0,429 & & & & \\
F-Statistik & 40,780 & & & & \\
Sig. & 0,000 & & & & \\
\hline
\end{tabular}

Sources: data proceed by IBM SPSS 20 
The coefficient of determination of the results of the moderation regression test was 0.429 referring to the adjusted R2 value. This means that the contribution of the influence that can be given by all independent variables is $42.9 \%$ or changes from the Financial Sustainability Ratio can be explained by all independent variables of $42.9 \%$ with the remaining $57.1 \%$ explained by all other independent variables outside this research. Then whether the contribution of $42.9 \%$ can have a simultaneous effect or not, it is proven by simultaneous testing of $\mathrm{F}$.

\subsection{Discussion Analysis}

The research findings show hypothesis 1 which states that Return on Assets (ROA) has a significant positive effect on the Financial Sustainability Ratio (FSR), based on table 6, known that the ROA variable has a positive coefficient of 1.752, while the one-tailed significance value obtained from the t-test results is 0.000 which is smaller than 0.05 , so this study can reject $\mathrm{H} 0$ so that the $\mathrm{H} 1$ of this study can be supported. the results of this study conclude that Return on Assets has a significant positive effect on the Financial Sustainability Ratio (FSR). The greater the Return On Assets (ROA) of a rural bank, the greater the level of profit achieved by the rural bank and the better the position of the rural bank in terms of the use of its assets so that the rural bank's ability to continue to be a going concern is higher. This result consistence with previous research from Almilia et al, Budiarti, Wahyuni and Fakhruddin's, Nyankomo and Meshach [1]-[3], [9].

The finding of the second hypothesis indicated that Non-Performing Loans (NPL) have a significant negative effect on the Financial Sustainability Ratio (FSR), based on table 6, known that the NPL variable has a negative coefficient of -0.008 , while the 1-tailed significance value obtained from the t-test results is 0.000 which is smaller than 0.05 , so this study can reject $\mathrm{H} 0$ so that the $\mathrm{H} 2$ of this study can be supported. NPL ratio This ratio shows that the ability of rural bank management to manage non-performing loans provided by rural banks. So that the result of this study conclude the lower this ratio shows the ability of bank management to manage non-performing loans provided by banks, the better so that the bank's ability to go concern is getting better. This result consistence with previous research from such as Almilia et al, Budiarti, Wahyuni and Fakhruddin's [1]-[3].

Hypothesis 3 indicated that Deposit Mobilization (DM) has a significant positive effect on the Financial Sustainability Ratio (FSR), based on table 6, known that the DM variable has a negative coefficient of -0.028 , while the one-tailed significance value obtained from the t-test results is 0.332 , which is greater than 0.05 , so this study cannot reject $\mathrm{H} 0$ so that the $\mathrm{H} 3$ of this study cannot be supported. There are several reasons why DM has no effect on financial sustainability ratio including: (i) the ability of rural banks to provide financing to customers (2) The large amount of mobilization deposit raises large costs, so a strategic plan is needed to manage it well (3) effect of bank liquidity, the lower the liquidity capacity of the bank concerned (the amount of funds needed to finance credit is getting bigger). This further worsens the ability of banks to go concern (4) based on life cycle theory the increase in deposit mobilization will bring the bank into phase II (youth) and then move up to phase III (mature). Because in both phases, savings services began to be improved and banks in phase III were characterized as banks with large customer bases. And finally we are looking from rural bank function in carrying out its business activities, RBs are not allowed to accept deposits in the form of demand deposits, conduct foreign exchange business activities, make capital investments using prudent banking principles, and carry out insurance business. So, the effort carried out by the rural bank's is to collect funds and distribute them with the aim of obtaining profits through the spread effect and interest income. 


\section{Conclusion}

From the findings of this study, it was concluded that:

1. Return on Assets has a significant positive effect on the Financial Sustainability Ratio (FSR). greater the ROA of a bank, the greater the level of profit achieved by the bank and the better the position of the bank in terms of the use of its assets so that the bank's ability to continue to be a sustainability financial is higher.

2. Non-Performing Loans (NPL) have a significant negative effect on the Financial Sustainability Ratio (FSR), the lower NPL ratio shows the ability of bank management to manage non-performing loans provided by banks, the better so that the bank's ability to going concern is getting better.

3. Deposit Mobilization (DM) had no significant positive effect on the Financial Sustainability Ratio (FSR) due to DM variable has a negative coefficient and significant value greater than $0.05 \%$. there is no effect on the DM variable. The rural banks are a microfinance institution that serve small business so that liquidity is highly dependent on the funds raised and distribute of financing to micro entrepreneurs and rural banks have limited liabilities product only saving and deposit.

\section{Limitations and Suggestion}

1. The researcher did not test the effect of BOPO, CAR and Micro economic variable such as sensitivity of money supply, interest rate, so it is recommended to do the test in the future.

2. This study only uses a sample of 71 companies Registered and supervised by the Financial Services Authority (OJK) in 2018-2020. Future research is expected to add a sample of companies.

3. This research does not classify companies based on core capital so that the further research performs based on bucket

\section{Implications}

The empirical evidence found from the results of this study has several implications as follows.

1. For companies to consider ROA and NPL that can effect financial sustainability so that manager required to carry out regular monitoring financial reports to mitigate financial distress and define strategy funding $\&$ financing.

2. For regulators' always maintenance and monitor financial performing reports and provide direction to bank management to maintain company liquidity and NPL as well.

3. For user information in the Indonesian capital market the level of financial ration in a company's annual report is valuable information that deserves to be considered as one of the criteria for rational investment decision making by investors.

\section{References}

[1] A. Budiarti, "Analisis Faktor-faktor yang Mempengaruhi Sustainabilitas Keuangan pada Perbankan di Indonesia Periode 2004-2011,” Institut Pertanian Bogor, 2012.

[2] S. Wahyuni dan I. Fakhruddin, "Analisis Faktor-faktor yang Mempengaruhi Sustainability Ratio Perbankan Syariah di Indonesia," in Seminar Nasional dan The 1st 
Call For Syariah Paper (SANCALL) 2014, hlm. 113-128.

[3] L. S. Almilia, Shonhadji, dan Anggraini, "Faktor-faktor yang Mempengaruhi Financial Sustainability Ratio pada Bank Umum Swasta Nasional Non Devisa Periode 19952005,” J. Akunt. dan Keuang., vol. 11, no. 1, hlm. 1-16, 2009.

[4] B. A. N. Fadhila, "Analisis Faktor-faktor yang Mempengaruhi Financial Sustainability Ratio pada Bank Umum Swasta Nasional Devisa Periode 2003-2009," Universitas Diponegoro, 2011.

[5] A. A. Mussa, "Sustainability of Higher Education Students' Loan Scheme (HESLS) in Tanzania,” Eur. J. Bus. Manag., vol. 7, no. 9, hlm. 149-163, 2015.

[6] T. A. Tehulu, "Determinants of Financial Sustainability of Microfinance Institutions in East Africa," Eur. J. Bus. Manag., vol. 5, no. 17, hlm. 152-158, 2013.

[7] V. Bogan, "Does Capital Structure Affect the Financial Sustainability of Microfinance Institutions?” Jan 01, 2007.

[8] J. Ndambu, "Does Regulation Microfinance Performance in Sub-Saharan Africa?," Frankfurt Sch. Financ. Manag. J., vol. 3, hlm. 1-11, 2011.

[9] N. Marwa dan M. Aziakpono, "Financial sustainability of Tanzanian saving and credit cooperatives," Int. J. Soc. Econ., vol. 42, no. 10, hlm. 870-887, Jan 2015, doi: 10.1108/IJSE-06-2014-0127.

[10] M. A. Rahman dan A. R. Mazlan, "Determinants of Financial Sustainability of Microfinance Institutions in Bangladesh," J. Econ. Financ., vol. 6, no. 9, hlm. 107116, 2014.

[11] R. Mersland dan L. Urgeghe, "Performance and International Investments in Microfinance Institutions,” J. Int. Debt Financ., vol. 12, no. 1-2, hlm. 17-29, 2013.

[12] D. Fehr dan G. Hishigsuren, "Raising Capital for Microfinance: Sources of Funding and Opportunities for Equity Financing," J. Dev. Entrep., vol. 11, no. 2, hlm. 133-143, 2006.

[13] S. Kazemian, R. A. Rahman, Z. M. Sanusi, dan A. A. Adewale, "Role of market orientation in sustainable performance: The case of a leading microfinance provider," Humanomics, vol. 32, no. 3, hlm. 352-375, 2016.

[14] M. Mwangi, W. Muturi, dan C. Ombuki, "The Effect of Deposit to Asset Ratio on The Financial Sustainability of Deposit Taking Micro Finance Institutions in Kenya," Int. J. Econ. Commer. Manag., vol. 3, hlm. 504-511, 2015.

[15] I. Ghozali, Aplikasi Analisis Multivariat dengan Program IBM SPSS 21, 7 ed. Semarang: Penerbit Universitas Diponegoro, 2011. 